\title{
PACI receptor (ADCYAPIRI) genotype and problematic alcohol use in a sample of young women
}

\author{
Wojciech Łukasz Dragan' \\ Piotr M Czerski² \\ Małgorzata Dragan ${ }^{3}$
}

'The Interdisciplinary Center for Behavior Genetic Research, Faculty of Psychology, University of Warsaw, Warsaw, ${ }^{2}$ Laboratory of Psychiatric Genetics, Poznan University of Medical Sciences, Poznan, ${ }^{3}$ Faculty of Psychology, University of Warsaw, Warsaw, Poland

Correspondence: Wojciech Łukasz Dragan

The Interdisciplinary Center for Behavior Genetic Research, Faculty of Psychology, University of Warsaw, Stawki Str 5/7, 00-I83 Warsaw, Poland Email wdragan@psych.uw.edu.pl
This article was published in the following Dove Press journal:

Neuropsychiatric Disease and Treatment

8 June 2017

Number of times this article has been viewed

Background: Recent studies revealed the role of the PAC1 (ADCYAP1R1) gene variability in vulnerability to posttraumatic stress disorder in women. Due to the relatively high comorbidity of posttraumatic stress disorder and substance use disorder, we hypothesized about possible associations between $P A C 1$ gene and problematic alcohol use.

Method: The sample studied consisted of 491 women aged 18 -28 years (mean age $=21$. 76 years; $\mathrm{SD}=1.83$ ) and the Alcohol Use Disorders Identification Test was used to assess drinking problems. We successfully genotyped 17 single-nucleotide polymorphisms in the $P A C 1$ gene.

Results: Single locus analysis revealed a significant (after correction for multiple testing) association between intronic polymorphism rs 2302475 and problematic alcohol use $(P=0.00048$; recessive model). This result was strengthened by the haplotype analysis $(P=0.00379)$.

Conclusion: Our results suggest that the PACAP/PAC1 signaling system is implicated in the development of problematic alcohol use in women.

Keywords: problematic alcohol use, $P A C l$ gene, AUDIT, HPA axis

\section{Introduction}

Pituitary adenylate cyclase-activating polypeptide (PACAP) and its receptor (PAC1) are implicated in regulating stress response. Their role is particularly important in the bed nucleus of the stria terminalis (BNST), where PACAP-containing neurons interact closely with neurons containing corticotropin-releasing hormone (CRH), ${ }^{1}$ which is secreted when a stressor activates the hypothalamic-pituitary-adrenal (HPA) axis. Furthermore, high concentrations of PACl were identified in several other brain regions, that is, the amygdala, hippocampus and cerebellum..$^{-4}$ The gene coding for PAC1 was related with stress-related disorders due to its links to the stress response system. Recently Ressler et al ${ }^{5}$ revealed a significant association between PAC1 (ADCYAP1R1) gene polymorphism (rs2267735) and proneness to posttraumatic stress disorder (PTSD). The authors also showed that methylation of $A D C Y A P 1 R 1$ was related to PTSD. One study failed to replicate Ressler et al's finding. ${ }^{6}$ However, two others found an interaction effect of genotype and trauma. ${ }^{7,8}$ Interestingly, the Ressler et al's study ${ }^{5}$ showed the association only in women. This effect is probably due to the localization of rs2267735 in a putative estrogen response element (ERE). It should also be noted that $P A C 1$ variability was associated with the darkenhanced startle response ${ }^{9}$ and increased reactivity of the amygdala and hippocampus to threat stimuli. ${ }^{10}$ Additionally, Pohlack et a ${ }^{11}$ found a link between $P A C l$ and impaired contextual conditioning in the hippocampus. However, the latter study did not confirm the association between the genotype and PTSD. 
Exposure to trauma and subsequent mental health problems are indicated as potential risk factors for problematic alcohol use, and the comorbidity of PTSD and substance use disorder (SUD) is relatively high. Several lines of evidence suggest neurobiological mechanisms are shared by the PTSD and SUD. ${ }^{12}$ One promising area of research in this domain involves understanding the role of the HPA axis activity, especially in the context of stress-related CRH neurocircuitries. ${ }^{13}$ The BNST seems to be the key structure responsible for integration of stress and reward information and mediating the negative affective state associated with excessive alcohol use. ${ }^{14}$ Recently Blasio et al ${ }^{15}$ revealed a role of the PACAP/PAC1 system in alcohol consumption in rats. One may speculate that part of this process is mediated through BNST action.

Vulnerability to problematic alcohol use is substantially genetic in nature. ${ }^{16}$ Among the leading candidate genes for SUD are those which code for subunits of the inhibitory $\mathrm{GABA}_{\mathrm{A}}$ and glycine receptors and proteins responsible for alcohol metabolism. ${ }^{17}$ To the best of our knowledge, there is no reported work that explores the role of $P A C 1$ (ADCYAPIR1) variability in the development of problematic alcohol use. The main aim of this study was to identify possible links between polymorphisms in $P A C l$ gene and problematic alcohol use in a sample of young women. This sample was chosen due to the aforementioned sex-specific association between rs2267735 and PTSD.

\section{Methods}

\section{Participants}

The participants were 502 young women with a mean age (M) $=21.78$ ( $\mathrm{SD}=1.84$; range $18-28$ years). They were recruited via Facebook student groups; an exclusion criterion was being a student of psychology; inclusion criteria were sex (female) and age (18-25 years). The vast majority (99\%) were of Polish nationality (the remaining 1\% were Ukrainian or Swedish). Also, the vast majority (96\%) were single $(0.4 \%$ were married; the remainder marked the answer "other"). More than half of the participants (54.6\%) had received a secondary level education and the remaining had at least a Bachelor's degree. Participation in the study was voluntary and participants gave their informed consent. They completed the questionnaires individually; following completion, they were paid the equivalent of 10 USD. The study was approved by the Research Ethics Committee at the Faculty of Psychology, University of Warsaw. All subjects gave informed consent in accordance with the Declaration of Helsinki. The study was carried out between 2014 and 2016.

\section{Measures}

The Alcohol Use Disorders Identification Test (AUDIT) is a widely used instrument, developed as a screening tool by the World Health Organization for early identification of problem drinkers. ${ }^{18}$ AUDIT consists of 10 questions regarding recent alcohol consumption, alcohol dependence symptoms and alcohol-related problems. The total score ranges from 0 , indicating no presence of problem drinking behavior, to 40 , indicating marked levels of problem drinking behavior. The threshold for indicating possible (moderate) drinking problems is a score of 8 . AUDIT possesses good psychometric properties. ${ }^{19}$ In the present study, the Cronbach's alpha for the total score was 0.81 .

\section{Genotyping}

DNA was isolated for all participants. The biological material was obtained from saliva using the Oragene ${ }^{\circledR}$ saliva collection system (DNA Genotek Inc., Ottawa, ON, Canada) and extracted using the provided protocol. Twenty-four singlenucleotide polymorphisms (SNPs) located within the $P A C 1$ (ADCYAP1R1) gene were selected for genotyping based on the existing literature and the HapMap database. We included the following SNPs: rs7794247; rs1157655; rs7784067; rs4439020; rs1981701; rs35413074; rs10241138; rs10226318; rs17723231; rs1006622; rs17159873; rs12533865; rs887703; rs12668955; rs2302475; rs1541516; rs2267732; rs2267733; rs2267735; rs2267737; rs2267738; rs2267740; rs4723047 and rs4503014. The Sequenom iPLEX ${ }^{\circledR}$ Gold assay was used for SNP genotyping following the manufacturer's protocol. ${ }^{20}$ This genotyping method utilizes matrix-assisted laser desorption ionization-time of flight mass spectrometry to determine genotypes based on the mass of allele-specific fragments. ${ }^{21}$

\section{Statistical analyses}

In order to test association between the selected SNPs, as the independent variables, and the AUDIT scale results, as the dependent variable, the following analysis of covariance (ANCOVA) models including age as a covariate were used:

1. dominant ( $\mathrm{AA}+\mathrm{AB}$ compared against $\mathrm{BB})$,

2. recessive ( $A A$ compared against $A B+B B$ ),

3. multiplicative ( $\mathrm{AB}$ compared against $\mathrm{AA}+\mathrm{BB})$, where $\mathrm{A}$ is minor allele and $\mathrm{B}$ is major allele. SNPs of $P A C 1$ (ADCYAP1R1) were selected based on their minor allele frequency (MAF; $\geq 5 \%$ ) and completeness of genotyping $(\geq 75 \%)$ across all subjects who were included in the analysis. The denominator used in all SNP analyses was the number of all subjects. Recessive and multiplicative models were 
estimated only if the minor homozygote frequency of a given SNP was greater than or equal to $5 \%$.

Haplotypes of PACl (ADCYAP1R1) were constructed according to the Solid Spine of linkage disequilibrium (LD) approach ${ }^{22}$ based on the data of all subjects who were included in the analysis. In order to test association between the constructed haplotypes, as the independent variables, and the AUDIT scale results, as the dependent variable, an ANCOVA model including age as a covariate was used. The denominator used in all haplotype analyses was the number of DNA strands in all subjects, that is, double the number of those subjects. Haplotype models were estimated only for haplotypes whose frequencies were $\geq 5 \%$ across the number of the analyzed DNA strands.

The statistical significance of each genetic source of variation (SNP or haplotype) in the AUDIT scale results was assessed using a 3-step approach. The first step was to calculate the $P$-value for the corresponding $F$-value of the given source's mean square (type III). The second step was about correcting the calculated $P$-value by dividing it by the number of ANCOVA models estimated for the given source (1 or 3 ). The third step involved analysis of correlation matrices for all the analyzed genetic sources (selected SNPs or constructed haplotypes, respectively) to determine the study-wide effective level of significance $\left(V_{\text {eff }}\right){ }^{23}$ The correlation matrices were calculated based on Spearman's rho statistic and using pairwise exclusion of missing observations.

All supplied means and SDs of the AUDIT scale results are descriptive and not least-square estimates. All analyses were performed with the use of SAS software version 9.3. ${ }^{24}$ Haploview software (version 4.2; Broad Institute, Cambridge, MA, USA $)^{22}$ was used to estimate the MAF and HardyWeinberg equilibrium (HWE) $P$-value and to visualize LD patterns and the haplotype map.

\section{Results}

Due to incomplete data, 11 women were excluded from the analyses. The final analysis population consisted of 491 subjects aged, $\mathrm{M}=21.76$ ( $\mathrm{SD}=1.83$; range $18-28$ years). One hundred and ninety participants ( $38.69 \%$ of the sample) had 8 or more points in the AUDIT questionnaire.

The following SNPs were excluded from the analysis due to technical problems with genotyping or MAF under 5\%: rs 7794247, rs4439020, rs1981701, rs17159873, rs2267732, rs2267735 and rs2267737. Genotype distributions for all remaining polymorphisms were in concordance with the HWE (Table 1).

Table I Single locus analyses for association of PACI gene polymorphisms and problematic alcohol use

\begin{tabular}{|c|c|c|c|c|c|}
\hline SNP & $\begin{array}{l}\text { HWE } \\
\text { P-value }\end{array}$ & Subjects - N (\%) & Model & $\begin{array}{l}\text { Means and SDs for } \\
\text { genotype groups }\end{array}$ & Statistics \\
\hline rsII57655 & 0.45 & $\begin{array}{l}\text { TT: } 24 \text { (4.9), GT: I85 } \\
\text { (37.7), GG: } 282 \text { (57.4) }\end{array}$ & Dominant & $\begin{array}{l}\text { not GG: } M=7.1 \mathrm{I}, \mathrm{SD}=4.68 \\
\mathrm{GG}: \mathrm{M}=6.98, \mathrm{SD}=4.54\end{array}$ & $\begin{array}{l}F=0.1 I \\
P=0.74573\end{array}$ \\
\hline \multirow[t]{3}{*}{ rs7784067 } & 1 & $\begin{array}{l}\text { CC: 9I (I8.5), CT: } 242 \\
\text { (49.3), TT: I58 (32.2) }\end{array}$ & Dominant & $\begin{array}{l}\text { not } \mathrm{TT}: \mathrm{M}=6.89, \mathrm{SD}=4.52 \\
\mathrm{TT}: \mathrm{M}=7.33, \mathrm{SD}=4.76\end{array}$ & $\begin{array}{l}F=1.11 \\
P=0.87917\end{array}$ \\
\hline & & & Recessive & $\begin{array}{l}C C: M=6.99, S D=5.02 ; \\
\operatorname{not} C C: M=7.05, S D=4.50\end{array}$ & $\begin{array}{l}F=0.02 \\
P=1\end{array}$ \\
\hline & & & Multiplicative & $\begin{array}{l}C T: M=6.86, S D=4.32 \\
\operatorname{not} C T: M=7.20, S D=4.85\end{array}$ & $\begin{array}{l}F=0.74 \\
P=1\end{array}$ \\
\hline rs354|3074 & 0.18 & $\begin{array}{l}\text { CC: } 24 \text { (4.9), AC: } 195 \\
(39.8), A A: 27 \text { I (55.3) }\end{array}$ & Dominant & $\begin{array}{l}\text { not } A A: M=6.78, S D=4.63 \\
A A: M=7.25, S D=4.58\end{array}$ & $\begin{array}{l}F=1.20 \\
P=0.27435\end{array}$ \\
\hline rs1024|138 & I & $\begin{array}{l}\text { CC: } 5 \text { (I.0), CT: } 92 \\
\text { (I8.7), TT: } 394 \text { (80.2) }\end{array}$ & Dominant & $\begin{array}{l}\text { not } T T: M=7.69, S D=5.25 \\
T T: M=6.87, S D=4.4 I\end{array}$ & $\begin{array}{l}F=2.57 \\
P=0.1098\end{array}$ \\
\hline \multirow[t]{3}{*}{ rs 10226318} & 0.28 & $\begin{array}{l}\text { GG: } 65 \text { (I3.2), GT: } 244 \\
\text { (49.7), TT: I82 (37.I) }\end{array}$ & Dominant & $\begin{array}{l}\text { not } T T: M=6.92, S D=4.71 \\
T T: M=7.24, S D=4.40\end{array}$ & $\begin{array}{l}F=0.52 \\
P=1\end{array}$ \\
\hline & & & Recessive & $\begin{array}{l}\text { GG: } M=7.1 \mathrm{I}, \mathrm{SD}=4.82 ; \\
\text { not } \mathrm{GG}: M=7.02, \mathrm{SD}=4.57\end{array}$ & $\begin{array}{l}F=0.04 \\
P=1\end{array}$ \\
\hline & & & Multiplicative & $\begin{array}{l}\mathrm{GT}: \mathrm{M}=6.86, \mathrm{SD}=4.69 ; \\
\text { not } \mathrm{GT}: \mathrm{M}=7.2, \mathrm{SD}=4.5 \mathrm{I}\end{array}$ & $\begin{array}{l}F=0.70 \\
P=1\end{array}$ \\
\hline \multirow[t]{3}{*}{ rs 17723231} & 0.39 & $\begin{array}{l}\text { TT: } 43 \text { (8.8), CT: } 220 \\
\text { (44.8), CC: } 228 \text { (46.4) }\end{array}$ & Dominant & $\begin{array}{l}\text { not } C C: M=6.86, S D=4.67 \\
C C: M=7.24, S D=4.5 I\end{array}$ & $\begin{array}{l}F=0.86 \\
P=1\end{array}$ \\
\hline & & & Recessive & $\begin{array}{l}\text { TT: } M=7.07, S D=4.93 ; \\
\text { not TT: } M=7.03, S D=4.57\end{array}$ & $\begin{array}{l}F=0.01 \\
P=1\end{array}$ \\
\hline & & & Multiplicative & $\begin{array}{l}C T: M=6.82, S D=4.63 \\
\operatorname{not} C T: M=7.21, S D=4.57\end{array}$ & $\begin{array}{l}F=0.95 \\
P=0.99255\end{array}$ \\
\hline
\end{tabular}


Table I (Continued)

\begin{tabular}{|c|c|c|c|c|c|}
\hline SNP & $\begin{array}{l}\text { HWE } \\
P \text {-value }\end{array}$ & Subjects - N (\%) & Model & $\begin{array}{l}\text { Means and SDs for } \\
\text { genotype groups }\end{array}$ & Statistics \\
\hline \multirow[t]{3}{*}{ rsl006622 } & 0.59 & $\begin{array}{l}\text { CC: } 106 \text { (2I.6), CT: } 237 \\
(48.3), \text { TT: } 148 \text { (30.I) }\end{array}$ & Dominant & $\begin{array}{l}\text { not } \mathrm{TT}: \mathrm{M}=6.89, \mathrm{SD}=4.72 \\
\mathrm{TT}: \mathrm{M}=7.36, \mathrm{SD}=4.30\end{array}$ & $\begin{array}{l}F=1.15 \\
P=0.85196\end{array}$ \\
\hline & & & Recessive & $\begin{array}{l}C C: M=7.28, S D=5.14 \\
\text { not } C C: M=6.97, S D=4.44\end{array}$ & $\begin{array}{l}F=0.39 \\
P=1\end{array}$ \\
\hline & & & Multiplicative & $\begin{array}{l}C T: M=6.72, S D=4.52 ; \\
\text { not } C T: M=7.33, S D=4.66\end{array}$ & $\begin{array}{l}F=2.27 \\
P=0.39669\end{array}$ \\
\hline rs 12533865 & 0.99 & $\begin{array}{l}\text { CC: } 2 \text { (0.4), CT: } 53 \\
(10.8), \text { TT: } 436(88.8)\end{array}$ & Dominant & $\begin{array}{l}\text { not TT: } M=7.1 \mathrm{I}, \mathrm{SD}=5.2 \mathrm{I} \\
\mathrm{TT}: \mathrm{M}=7.03, \mathrm{SD}=4.52\end{array}$ & $\begin{array}{l}F=0.05 \\
P=0.82552\end{array}$ \\
\hline \multirow[t]{3}{*}{ rs887703 } & 0.19 & $\begin{array}{l}\text { GG: } 53 \text { (I0.8), AG: } 238 \\
\text { (48.5), AA: } 200 \text { (40.7) }\end{array}$ & Dominant & $\begin{array}{l}\text { not } A A: M=6.66, S D=4.5 I \\
A A: M=7.58, S D=4.67\end{array}$ & $\begin{array}{l}F=4.72 \\
P=0.09082\end{array}$ \\
\hline & & & Recessive & $\begin{array}{l}\text { GG: } M=8.15, S D=5.44 ; \\
\text { not } G G: M=6.90, S D=4.47\end{array}$ & $\begin{array}{l}F=3.12 \\
P=0.23466\end{array}$ \\
\hline & & & Multiplicative & $\begin{array}{l}\text { AG: } M=6.33, S D=4.22 ; \\
\text { not } A G: M=7.7, S D=4.84\end{array}$ & $\begin{array}{l}F=10.58 \\
P=0.00367\end{array}$ \\
\hline \multirow[t]{3}{*}{ rsI2668955 } & 0.23 & $\begin{array}{l}\text { AA: I26 (25.7), AG: 23I } \\
\text { (47.I), GG: I33 (27.I) }\end{array}$ & Dominant & $\begin{array}{l}\text { not GG: } M=7.24, S D=4.5 I \text {; } \\
\text { GG: } M=6.48, S D=4.80\end{array}$ & $\begin{array}{l}F=2.58 \\
P=0.32649\end{array}$ \\
\hline & & & Recessive & $\begin{array}{l}\text { AA: } M=7.7 \mathrm{I}, S D=4.8 \mathrm{I} \\
\text { not } A A: M=6.79, S D=4.5 \mathrm{I}\end{array}$ & $\begin{array}{l}F=3.66 \\
P=0.16882\end{array}$ \\
\hline & & & Multiplicative & $\begin{array}{l}\text { AG: } M=6.97, S D=4.34 \\
\text { not } A G: M=7.08, S D=4.83\end{array}$ & $\begin{array}{l}F=0.06 \\
P=1\end{array}$ \\
\hline \multirow[t]{3}{*}{ rs2302475 } & 0.56 & $\begin{array}{l}\text { CC: } 103 \text { (2I.0), CT: } 252 \\
\text { (5I.3), TT: } 136(27.7)\end{array}$ & Dominant & $\begin{array}{l}\text { not } \mathrm{TT}: M=6.9, \mathrm{SD}=4.44 \\
\mathrm{TT}: \mathrm{M}=7.39, \mathrm{SD}=4.97\end{array}$ & $\begin{array}{l}F=0.93 \\
P=1\end{array}$ \\
\hline & & & Recessive & $\begin{array}{l}C C: M=5.53, S D=4.25 \\
\text { not } C C: M=7.43, S D=4.61\end{array}$ & $\begin{array}{l}F=14.47 \\
P=0.00048\end{array}$ \\
\hline & & & Multiplicative & $\begin{array}{l}C T: M=7.46, S D=4.4 I \\
\text { not } C T: M=6.59, S D=4.75\end{array}$ & $\begin{array}{l}F=4.87 \\
P=0.08356\end{array}$ \\
\hline rs 1541516 & 0.95 & $\begin{array}{l}\text { AA: } 3 \text { (0.6), AG: } 80 \\
\text { (16.3), GG: } 408(83.1)\end{array}$ & Dominant & $\begin{array}{l}\text { not GG: } M=7.84, S D=5.40 \\
\text { GG: } M=6.87, S D=4.4 \mathrm{I}\end{array}$ & $\begin{array}{l}F=3.01 \\
P=0.08322\end{array}$ \\
\hline \multirow[t]{3}{*}{ rs2267733 } & 0.34 & $\begin{array}{l}\text { TT: 7I (I4.5), CT: } 246 \\
\text { (50.I), CC: I74 (35.4) }\end{array}$ & Dominant & $\begin{array}{l}\text { not } C C: M=7.30, S D=4.32 \\
C C: M=6.56, S D=5.04\end{array}$ & $\begin{array}{l}F=3.1 I \\
P=0.23599\end{array}$ \\
\hline & & & Recessive & $\begin{array}{l}\text { TT: } M=7.07, S D=4.32 \\
\text { not } T T: M=7.03, S D=4.65\end{array}$ & $\begin{array}{l}F=0.01 \\
P=1\end{array}$ \\
\hline & & & Multiplicative & $\begin{array}{l}\text { CT: } M=7.36, S D=4.33 \\
\text { not } C T: M=6.7 I, S D=4.84\end{array}$ & $\begin{array}{l}F=2.87 \\
P=0.27219\end{array}$ \\
\hline rs2267738 & 0.9 & $\begin{array}{l}\text { AA: } 22 \text { (4.5), AG: } 169 \\
\text { (34.4), GG: } 300(61.1)\end{array}$ & Dominant & $\begin{array}{l}\text { not GG: } M=7.32, S D=4.5 I \text {; } \\
\text { GG: } M=6.85, S D=4.65\end{array}$ & $\begin{array}{l}F=1.14 \\
P=0.28578\end{array}$ \\
\hline rs2267740 & 0.85 & $\begin{array}{l}\text { TT: } 8 \text { (I.6), CT: II } \\
(24.0), \text { CC: } 365 \text { (74.3) }\end{array}$ & Dominant & $\begin{array}{l}\text { not } C C: M=7.39, S D=4.19 \\
C C: M=6.91, S D=4.73\end{array}$ & $\begin{array}{l}F=1.01 \\
P=0.31479\end{array}$ \\
\hline rs4723047 & 0.86 & $\begin{array}{l}\text { CC: } 24 \text { (4.9), CG: } 175 \\
\text { (35.6), GG: } 292(59.5)\end{array}$ & Dominant & $\begin{array}{l}\text { not GG: } M=7.00, S D=4.65 \text {; } \\
\text { GG: } M=7.06, S D=4.57\end{array}$ & $\begin{array}{l}F=0.03 \\
P=0.873 \mathrm{II}\end{array}$ \\
\hline \multirow[t]{3}{*}{ rs45030I4 } & 1 & $\begin{array}{l}\text { GG: } 33 \text { (6.7), AG: I88 } \\
\text { (38.3), AA: } 270(55.0)\end{array}$ & Dominant & $\begin{array}{l}\text { not } A A: M=6.69, S D=4.42 \\
A A: M=7.31, S D=4.72\end{array}$ & $\begin{array}{l}F=2.30 \\
P=0.39121\end{array}$ \\
\hline & & & Recessive & $\begin{array}{l}\text { GG: } M=5.58, S D=3.04 \\
\text { not } G G: M=7.14, S D=4.67\end{array}$ & $\begin{array}{l}F=3.58 \\
P=0.17700\end{array}$ \\
\hline & & & Multiplicative & $\begin{array}{l}\text { AG: } M=6.89, S D=4.60 \\
\text { not } A G: M=7.13, S D=4.60\end{array}$ & $\begin{array}{l}F=0.33 \\
P=1\end{array}$ \\
\hline
\end{tabular}

Notes: Percentages are based on the number of all subjects included in the analysis $(\mathrm{N}=49 \mathrm{I})$. Percentages not summing up to 100 are due to rounding. Statistics are based on analysis of covariance (ANCOVA) model including age as a covariate. All supplied means and SDs are descriptive and not least-square estimates.

Abbreviations: SNP, single nucleotide polymorphism; HWE, Hardy-Weinberg equilibrium; SD, standard deviation.

Assuming the recessive model, we identified significant (after correction for multiple testing) association between rs2302475 and AUDIT scale results $-F(1,478)=14.473$, $P=0.00048$. We did not find any associations between other SNPs within the PAC1 (ADCYAP1R1) gene and the dependent variable. The specific results for all SNPs are presented in Table 1.
In our sample, we identified 4 separate haploblocks. The pairwise LD patterns are presented in Figure 1.

Haplotype reconstruction revealed 3 haplotypes in block 4, reaching estimated frequencies of 5\% or more. Means and SDs of AUDIT total scores for identified haplogroups were as follows: $\mathrm{CG}-\mathrm{M}=6.61, \mathrm{SD}=4.4$; $\mathrm{TA}-$ $\mathrm{M}=8.36, \mathrm{SD}=5.58 ; \mathrm{TG}-\mathrm{M}=7.28, \mathrm{SD}=4.53$. We identified 


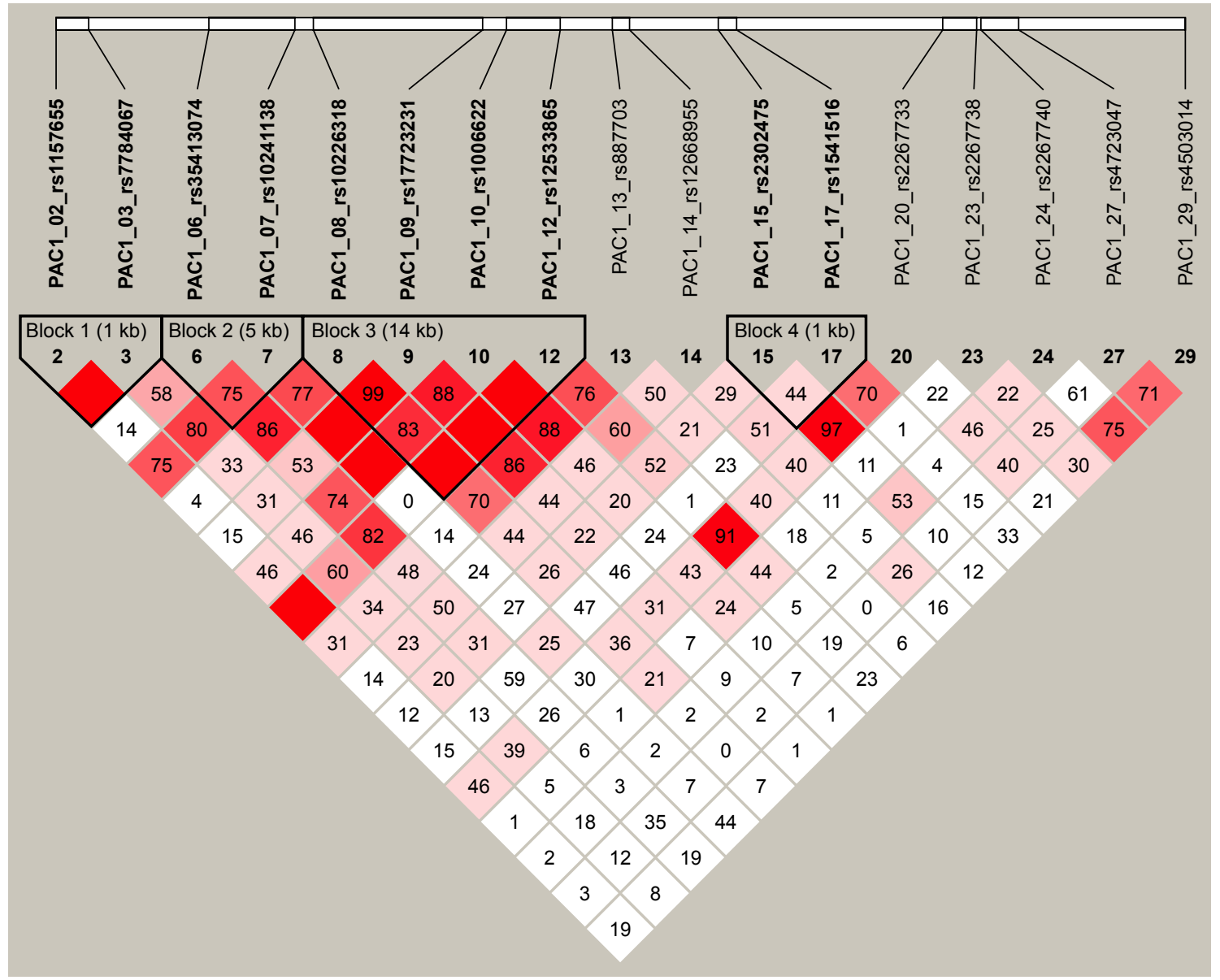

Figure I Diagram of block structure of PACI gene generated using Haploview.

a significant (after correction for multiple testing) main effect of haplotype $-F(2,963)=5.61, P=0.00379$. The TukeyKramer post hoc test showed significant difference between CG and TA groups ( $P=0.0066)$.

\section{Discussion}

Recent studies revealed that the PAC1 (ADCYAP1Rl) gene plays a role in the risk for PTSD in women. ${ }^{5,7}$ Our study aimed to identify possible relations between $P A C 1$ polymorphisms and problematic alcohol use in a sample of young women. We showed the strong impact of the rs2302475 SNP on AUDIT scores. The relevance of this polymorphism was further supported by the results of haplotype analysis. The rs2302475 polymorphism was previously related to schizophrenia in one study ${ }^{2}$ - the $\mathrm{T}$ allele was identified as a risk factor. In our study, the CC genotype was associated with lower levels of problematic alcohol use as measured by the AUDIT. It therefore seems likely that the $\mathrm{T}$ allele increases the risk of psychiatric disorders, which, in part, may be causally related to HPA axis activity. ${ }^{25,26}$ It should be noted, however, that a different polymorphic site (ie, rs2267735) was linked to PTSD in a sample of women in previous studies. ${ }^{5}$ This sex-specific relation is due to the presence of an ERE in the intron region containing this SNP. Our study was designed to expand the phenotypic spectrum associated with PACl (ADCYAP1R1) gene in young females. However, due to technical problems, we were not able to genotype rs2267735 in our sample. Thus, it was not possible to test sex-specific effects related to this polymorphism. The region adjacent to rs2302475 probably does not contain an ERE. We conducted a computer-assisted homology search of the sequence of this region using an ERE-prediction program (Dragon ERE finder ver 3.0). ${ }^{27}$ The analysis did not reveal the existence of such regulatory elements. Therefore, it seems that the major limitation of our study is that it was conducted only on female participants. Replication attempts should include both sexes. We cannot rule out, however, that the association identified may be a consequence of $\mathrm{LD}$ between the two aforementioned polymorphisms. We calculated the LD for this SNP pair using 1,000 Genomes Project data and a web-based tool, SNAP. ${ }^{28}$ This analysis identified a strong LD between rs2302475 and rs2267735 ( $\left.D^{\prime}=0.85\right)$. Assuming 
that the obtained results indirectly represent the actual effect of rs2267735, one could treat them as a confirmation of Ressler et al's ${ }^{5}$ findings. Regardless of which SNP is the true cause of the results obtained in our study, one may speculate about the role of the PAC1 ( $A D C Y A P 1 R 1$ ) gene variability in the etiology of problematic alcohol use. Of course, our study is not without limitations. We mentioned above about the composition of the sample studied. We must also note that we used a self-rated measure of problematic alcohol use. Replication studies should include clinical samples and use semi-structured clinical interviews to diagnose problematic alcohol use. One of the potential limitations of this study is the lack of assessment of comorbid conditions such as anxiety, sleep or mood disorders. We cannot exclude the possibility that our findings reflect the impact of the $P A C 1$ ( $A D C Y A P 1 R 1)$ gene variability on these conditions and not on the problematic alcohol use.

\section{Conclusion}

In summary, we revealed the association between the rs2302475 polymorphism in the PACl (ADCYAP1R1) gene and problematic alcohol use among young women. Our findings were strengthened by the haplotype analysis. Our results indicate the role of the PACAP/PAC1 signaling system in vulnerability to problem drinking in women.

\section{Acknowledgment}

This study was supported by Ministry of Science and Higher Education Iuventus Plus grant no 0105/IP3/2011/71 and internal funds of the University of Warsaw.

\section{Disclosure}

The authors report no conflicts of interest in this work.

\section{References}

1. Hammack SE, Roman CW, Lezak KR, et al. Roles for pituitary adenylate cyclase-activating peptide (PACAP) expression and signaling in the bed nucleus of the stria terminalis (BNST) in mediating the behavioral consequences of chronic stress. J Mol Neurosci. 2010;42(3):327-340.

2. Hashimoto R, Hashimoto H, Shintani N, et al. Pituitary adenylate cyclaseactivating polypeptide is associated with schizophrenia. Mol Psychiatry. 2007;12(11):1026-1032.

3. Basille M, Cartier D, Vaudry D, et al. Localization and characterization of pituitary adenylate cyclase-activating polypeptide receptors in the human cerebellum during development. J Comp Neurol. 2006; 496(4):468-478.

4. Vaudry D, Falluel-Morel A, Bourgault S, et al. Pituitary adenylate cyclase-activating polypeptide and its receptors: 20 years after the discovery. Pharmacol Rev. 2009;61(3):283-357.

5. Ressler KJ, Mercer KB, Bradley B, et al. Post-traumatic stress disorder is associated with PACAP and the PAC1 receptor. Nat Genet. 2011; 470(7335):492-497.

6. Chang SC, Xie P, Anton RF, et al. No association between ADCYAP1R1 and post-traumatic stress disorder in two independent samples. Mol Psychiatry. 2012;17(3):239-241.
7. Uddin M, Chang SC, Zhang C, et al. Adcyap1r1 genotype, posttraumatic stress disorder, and depression among women exposed to childhood maltreatment. Depress Anxiety. 2013;30(3):251-258.

8. Almli LM, Mercer KB, Kerley K, et al. ADCYAP1R1 genotype associates with post-traumatic stress symptoms in highly traumatized African-American Females. Am J Med Genet B Neuropsychiatr Genet. 2013;162B(3):262-272.

9. Jovanovic T, Norrholm SD, Davis J, et al. PAC1 receptor (ADCYAP1R1) genotype is associated with dark-enhanced startle in children. Mol Psychiatry. 2012;18(7):742-743.

10. Stevens JS, Almli LM, Fani N, et al. PACAP receptor gene polymorphism impacts fear responses in the amygdala and hippocampus. Proc Natl Acad Sci U S A. 2014;111(8):3158-3163.

11. Pohlack ST, Nees F, Ruttorf M, et al. Neural mechanism of a sex-specific risk variant for posttraumatic stress disorder in the type I receptor of the pituitary adenylate cyclase activating polypeptide. Biol Psychiatry. 2015;78(12):840-847.

12. Norman SB, Myers US, Wilkins KC, et al. Review of biological mechanisms and pharmacological treatments of comorbid PTSD and substance use disorder. Neuropharmacology. 2012;62(2):542-551.

13. Zorrilla EP, Logrip ML, Koob GF. Corticotropin releasing factor: a key role in the neurobiology of addiction. Front Neuroendocrinol. 2014; 35(2):234-244.

14. Kash TL, Pleil KE, Marcinkiewcz CA, et al. Neuropeptide regulation of signaling and behavior in the BNST. Mol Cells. 2015;38(1):1-13.

15. Blasio A, Ferragud A, Dileo AC, et al. The Pacap/Pac1 system regulates excessive alcohol consumption. Alcohol Clin Exp Res. 2015; 39(Supp 1):235A.

16. Enoch MA. Genetic influences on the development of alcoholism. Curr Psychiatry Rep. 2013;15(11):412.

17. Trudell JR, Messing RO, Mayfield J, Harris RA. Alcohol dependence: molecular and behavioral evidence. Trends Pharmacol Sci. 2014; 35(7):317-323.

18. Babor TF, La Fuente De JR, Saunders JB, Grant M. AUDIT-the Alcohol Use Disorders Identification Test: Guidelines for Use in Primary Health Care World Health Organization. Geneva: World Health Organization; 1989.

19. de Meneses-Gaya C, Zuardi AW, Loureiro SR, Crippa JAS. Alcohol Use Disorders Identification Test (AUDIT): an updated systematic review of psychometric properties. Psychol Neurosci. 2009;2(1):83-97.

20. Jurinke C, van den Boom D, Cantor CR, Köster H. Automated genotyping using the DNA MassArray technology. Methods Mol Biol. 2002; 187:179-192.

21. Wright WT, Heggarty SV, Young IS, et al. Multiplex MassARRAY spectrometry (iPLEX) produces a fast and economical test for 56 familial hypercholesterolaemia-causing mutations - PubMed - NCBI. Clin Genet. 2008;74(5):463-468.

22. Barrett JC, Fry B, Maller J, Daly MJ. Haploview: analysis and visualization of LD and haplotype maps. Bioinformatics. 2005;21(2): 263-265.

23. Li J, Ji L. Adjusting multiple testing in multilocus analyses using the eigenvalues of a correlation matrix. Heredity. 2005;95(3):221-227.

24. SAS Institute. SAS User's Guide: Statistics. Cary, NC; 2011.

25. Stephens MAC, Wand G. Stress and the HPA axis: role of glucocorticoids in alcohol dependence. Alcohol Res. 2012;34(4):468-483.

26. Walker E, Mittal V, Tessner K. Stress and the hypothalamic pituitary adrenal axis in the developmental course of schizophrenia. Annu Rev Clin Psychol. 2008;4(1):189-216.

27. Bajic VB, Tan SL, Chong A, et al. Dragon ERE Finder version 2: a tool for accurate detection and analysis of estrogen response elements in vertebrate genomes. Nucl Acids Res. 2003;31(13):3605-3607.

28. Johnson AD, Handsaker RE, Pulit SL, Nizzari MM, O'Donnell CJ, de Bakker PIW. SNAP: a web-based tool for identification and annotation of proxy SNPs using HapMap. Bioinformatics. 2008;24(24): 2938-2939. 
Neuropsychiatric Disease and Treatment

Dovepress

\section{Publish your work in this journal}

Neuropsychiatric Disease and Treatment is an international, peerreviewed journal of clinical therapeutics and pharmacology focusing on concise rapid reporting of clinical or pre-clinical studies on a range of neuropsychiatric and neurological disorders. This journal is indexed on PubMed Central, the 'PsycINFO' database and CAS,

and is the official journal of The International Neuropsychiatric Association (INA). The manuscript management system is completely online and includes a very quick and fair peer-review system, which is all easy to use. Visit http://www.dovepress.com/testimonials.php to read real quotes from published authors.

Submit your manuscript here: http://www.dovepress.com/neuropsychiatric-disease-and-treatment-journal 